\title{
Introducing 'Realizm'
}

\author{
Zia Ul Haque Shamsi ${ }^{1 *}$
}

\begin{abstract}
According to realist paradigm, the present international system is anarchic and selfish, and therefore needs to be reset, because the gap between the developed and developing nations has reached dangerous levels. The wars between Unequal Military Powers (UMPs), have ruined several states, particularly in the Middle East. While the causes of such wars would be debated for a long time, the outcome is extremely dreadful for the people of Iraq, Syria, Libya, Afghanistan, Palestine, Kashmir, and Yemen, to name the few. Therefore, there is a need to do away with old schools of realism, liberalism, or the constructivism, which have failed to maintain peace, stability, and security of the people particularly in developing world. Adopting an inductive reasoning approach, the aim of the study is to present a revised international relations' theory to reset the flawed international system, supported with the qualitative data. The rephrased political theory of realizm focuses on self-realization, mutual assistance and common good, for regional development; with a view that global peace is possible through cooperation with prudence for safety, security, and stability of the international system.
\end{abstract}

Keywords: Realism; Liberalism; Realizm; Security; Unequal Military Powers.

\section{Introduction}

During the cold war, the two superpowers were fighting their wars through the proxies and avoided a direct military confrontation. The only time both United States (US), and the Soviet Union (USSR) faced off directly was during the Cuban Missile Crisis in 1962. Since the collapse of the erstwhile USSR, and the beginning of 'New World Order' in the early 1990s, the nature and character of wars and conflict has completely changed. Over the past three decades, most wars have been fought between the 'Unequal Military Powers' (UMPs) led by the US and its western allies, against any one country in a particular region: The Middle East. The results of such wars were obvious with the weaker being destroyed completely, and its people continue to suffer to date. Therefore, the situation arising out of wars between UMPs call for an introduction of an alternate approach to age-old international relations' theories and practices under the realist and liberalist paradigm.

The COVID-19 has shaken the world. It was first discovered in Wuhan, China in November 2019. However, at that time nobody on this planet earth could imagine that it would turn into a 'Pandemic' inflicting serious harm to human lives in over 200 states and territories. Till date, China has reported

${ }^{1}$ The Centre for Aerospace and Security Studies (CASS), Islamabad, Pakistan.

*)Corresponding Author.

Email: ziashamsi99@yahoo.com 
less than 6000 deaths as against over 700,000 in the United States, over 600,000 in Brazil, 138,000 in UK, 450,000 in India, 130,000 in Italy, and 114,000 in France, to mention the few.

The objective of this study is to highlight the failure of existing international relations theories; mainly realism, liberalism, and constructivism, to bring peace and stability in the developing regions. Realist paradigm was too realistic, and nations followed its precepts in letter and spirit. The rich nations continued to grow in the garb of national interests, and poor states continued to decline on Human Development Indices, because the selfish nature of states under the realist paradigm did not care for the weak. Though, there were other reasons too.

The liberal precepts were too idealistic, and therefore these could not serve the right purpose for the richer and developed nations. Liberals' called for globalized citizenry, and international cooperation were considered against the very human nature of desire for power and security as per the realist paradigm. Therefore, most wars and conflicts which started adopting the realists' approach, were also blamed on liberal thoughts to be impracticable.

The constructivism also lost its way finding ideas and identities. The promotion of social groupings and institutions could only serve the purpose of some welfare works. Despite claims for being innovative in their approach, constructivists failed to broaden the understanding of stakeholders about the issues of the developing world which needed attention of the developed world.

Therefore, this author is proposing a rephrased alternate approach; realizm which may help in minimizing the wars and conflicts between UMPs, leading to a more even regional development than a particular state. The global peace is considered possible through equitable regional development, which may help reduce the migrations of the people from the developing countries toward the developed world. The same would help develop each nation's capacity to deal with Pandemics like COVID-19, and the man-made crises like wars and conflicts between UMPs.

The very purpose of introducing this new political theory of realizm is to minimize the probabilities of wars and conflicts between UMPs so that the people in the weaker states, do not suffer the way we have seen in the recent past. This author is of the view that a handful of realizers can prove to be game-changers, and alter the course of history for the betterment of humanity.

To impress upon the argument that global peace and stability is possible through regional cooperation, compassion, and prudence; this new theory of realizm is proposed for the discussion by academia and experts on the subject. The purpose is to avert the 'next' war or conflict between UMPs, following the proposed precepts under the realized paradigm.

This author is of the view that most of the wars and conflicts of recent past, particularly between UMPs, are the result of age-old political theories pronounced by the likes of Chanakya Kautilya, Niccolo Machiavelli, and others who followed their precepts. For them, morality was of no concern, and interests of the state were supreme and must be accomplished by any means. 
Some of these important theories are reviewed in the following paragraphs to understand the present chaotic international order.

\section{Theoretical Precepts: Realism and State}

The international realm is anarchic. It consists of independent political units called states, which are the primary actors (Jackson \& Sorensen, 2007). All states maintain certain levels of offensive military capability which may be perceived as potentially dangerous by other states (Morgenthau, 1948). Hence, states remain unsure about the intentions of other states and continue to enhance their power base to remain sovereign. However, most states think rationally and consolidate themselves to survive in the anarchic environment (Morgenthau, 1948). Major international relations' theories agreed with the concept of a state, as a unitary actor pursuing its respective national interests to achieve their political objectives.

The Treaty of Westphalia (1648), gave birth to the concept of nation states and provided a comprehensive framework of interrelationship between them. The 'Treaty' provided meaning to words like sovereignty and international relations. The concept of state drew the boundaries across Europe, and subsequently elsewhere also. State is as an integrated society which possesses a coercive authority legally supreme over an individual or group, which is a part of that society (Laski, 1935). Whereas, the state provides, for the maintenance of domestic peace such as legal continuity to the national society, institutionalized agencies for the processes of social change and the agencies for the enforcement of its laws (Morgenthau, 1973). The state provides the framework, politico-legal, as well in terms of allocation of values, which characterizes the dissent of dissenting groups in the society and also the means of expression of this dissent such as violence etc. In other words, state's function for the maintenance of domestic peace is to provide the legal continuity of the national society. It is the state that provides most of the institutionalized agencies and processes of social change, and the agencies for the enforcement of its laws. State's contribution to domestic peace is the indispensable, but it is not in itself sufficient (Morgenthau, 1973).

While deliberating the role of state, it is necessary to view the alternate studies as well, which suggested that the state is best understood as protection racket and trades security in exchange of revenues (Tilly, 1985). In fact, use of state and government interchangeably causes negative perception about the role of state, therefore; this author would be using 'regime' for the government, instead of state. This argument can be supported with numerous examples from the developing countries where some leaders, to prolong their tenure in power, ran the state like a racket. President Mugabe of Zimbabwe introduced controversial land reforms just before 2002 elections to strengthen his position, nearly starved his people and state to the brink of disaster. Mugabe remained in power for over thirty years by exploiting the sentiments of the poor people who were too powerless to prevent him from doing so. North Korea under the communist regime of Kim Jong-un can also be placed 
in the same category. West European states experienced the same phenomenon during their early stages of state making; France under Bourbons and England under Tudor, to mention the few. Whereas, in the recent times, Iraq under Saddam Hussain, Libya under Muammar Qaddafi; Syria under Bashar Al Assad; and Afghanistan under Taliban were seen defying the internationally accepted norms and practices to manage the state, ultimately led their people to ruins. Whether these states should have been destroyed because of unwanted regimes, is an important matter for a comprehensive research. However, the destruction of the country's infrastructure, and deaths of millions of innocent people and large-scale displacement of the surviving population can never be justified. Unfortunately, most of these wars were permitted by international bodies which were responsible to ensure safety, and security for the innocent people on this planet earth.

\section{$\underline{\text { Realism and its Desired Fundamentals at a Glance }}$}

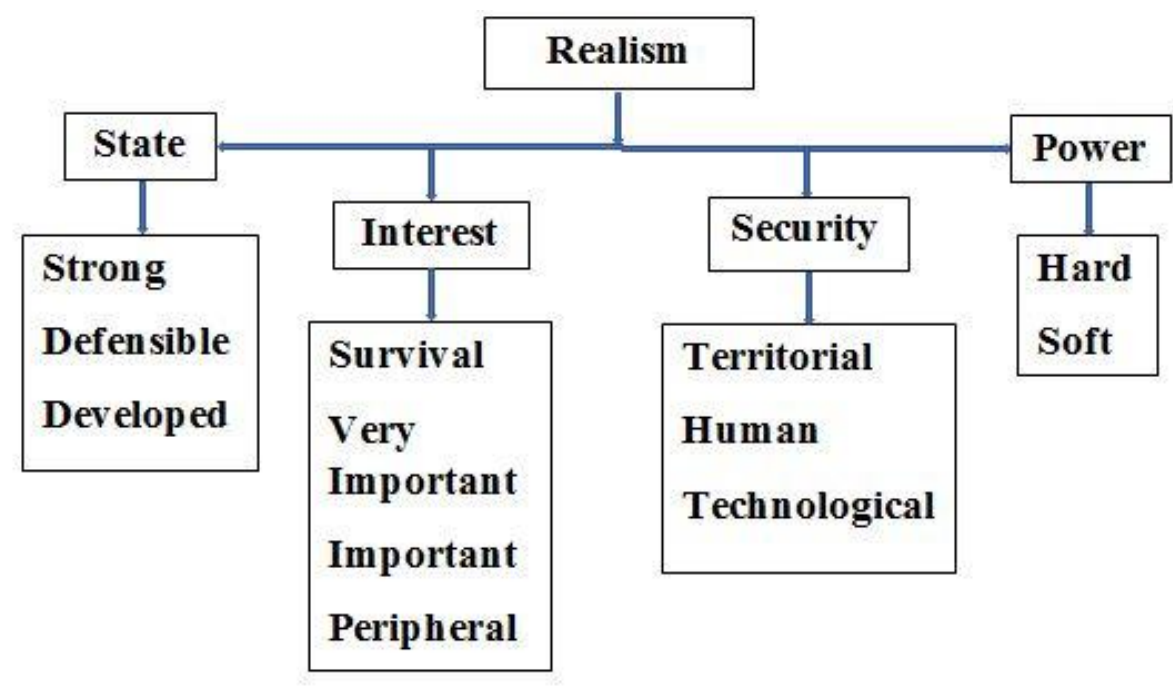

Figure-1

Perhaps, it is necessary to briefly explain the desired fundamentals of realism once again, as shown in Figure-1, to understand its popularity among the theories of international relations.

Each state, as the unitary unit in the present international system, would like to be strong, defendable, and developed. For the purpose, states would do anything to acquire power to ensure security and further its interests, Machiavellian approach. Each of these desired objectives under the realm of realism deserve a brief comment.

States desire to become regional hegemon, with global ambitions for the sake of prestige, and leverage over other weaker states in the region. States use this position on international forums to push their agenda of ideology, culture, and economic models using soft power. This helps states develop, even at the cost of others, and make them easily defendable with the available 
hard power; Kautilyan approach. States' desire for prestige, and being an influencer in the region, drives them to acquire more and more power to be able to challenge extra-regional powers too.

The national interests have been defined differently by the political theorists. It "describes the aspirations and goals of sovereign entities in the international arena" (Nuechterlein, 1976). Whereas, Dinesh quotes Hans J. Morgenthau for a more comprehensive definition of national interest, "The meaning of national interest is survival - the protection of physical, political and cultural identity against encroachments by other nation-states" (Dinesh, 2020). It is evident from the above definitions that survival forms the core of national interests, and therefore states can do anything under the pretext. Unfortunately, the stronger states can further their interest with relative ease, whereas the weaker ones have to compromise even on their vital interests.

Similarly, the security demands of the states give them the opportunity to gather more and more power, thereby creating 'security-insecurity dilemma' among the regional states. Stronger states in the region build up their military muscles to force their will on the relatively weaker states in the region. Regional hegemon combined their hard and soft power to pursue the agenda under the pretext of national interests, which are always vague but cannot be questioned under the present anarchic international system, according to realist paradigm.

To conclude the academic explanations about realism and state, this author is of the view that realists' with security for state and its interests for which power must be acquired by any means, has been the root cause of most wars particularly against the unequal military powers.

\section{Theoretical Precepts: Liberalism and Cooperation}

Liberals view that peace across borders is possible through cooperation and engagement. They lay emphasis on equality, liberty, and protection of peoples' right to practice their morals and values. Liberals assert for ethical pursuits rather than acquisition of power for prestige. "The origins of liberal theory are found in Enlightenment optimism, nineteenth-century political and economic liberalism, and twentieth-century Wilsonian idealism (Mingst, 2008). Leading liberals like Immanuel Kant was of the view that avoidance of war is possible, though difficult. He asserts that the formation of a federation of states could help overcome the anarchy of the international system (Ninkovic, 1957). Kant's liberalism advocated global citizenship, and free trade.

The other liberal theorists prophesied on international cooperation, international norms, and interdependence among states (Kegley, Wittkopt \& Eugene, 2004). They strived for world peace, because they did not see human being as bad by nature. However, liberals' views were severely criticized for events during the World War I and therefore liberal thoughts and ideas underwent transformations to reach the idea of creating international institutions to replace the anarchical state of the world. Collective security was one of the ideas which led to the formation of League of Nations on January 
10, 1920. Other ideas propounded by liberals included the establishment of Permanent Court of International Justice in 1921, ratification of KelloggBriand Pact of 1928, and efforts toward the arms control and disarmament agreements during the 1920s. However, about the Kellogg-Briand Pact; it was declared that it was a, "... misplaced idealism that failed to stop the slide to war and may have made it a bit more likely...." (Walt, 2017). Liberalism or idealism was declared as 'impractical' primarily due its sweetness. No serious effort was made to ensure that people of weaker nations may also get the same level of security as is available to developed and stronger nations. Universal values, international laws and organizations created on the basis of liberal precepts miserably failed when it came to rights and privileges of the weak and poor.

\section{Liberalism and its Desired Fundamentals at a Glance}

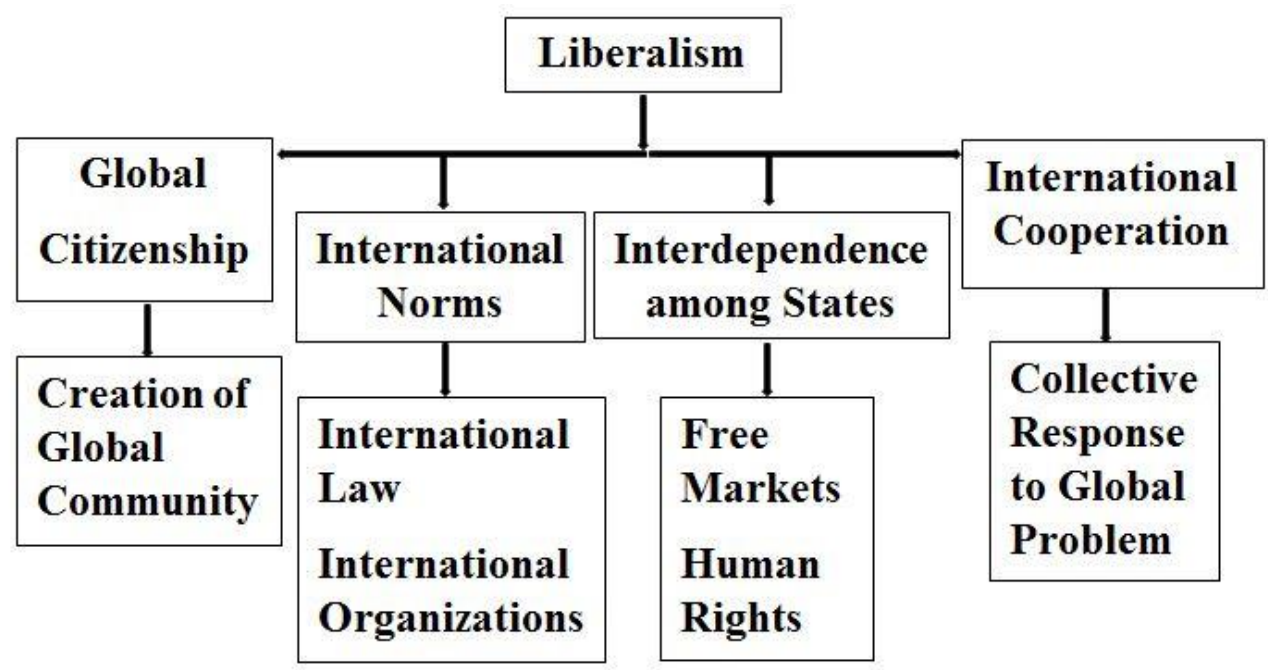

\section{$\underline{\text { Figure-2 }}$}

The Figure- 2 shows an ideal picture which could not be achieved, and the world saw some of the most devastative wars and conflicts even when the League of Nation, International Court of Justice, Human Rights Organizations, and the United Nations are in place. The un-fulfillment of the liberals' ideals was mainly attributed to unrealistic targets challenging the basic nature of the human beings. However, this author is of the view that a beginning may be made to minimize the probabilities of wars and conflicts between unequal military powers. This would certainly help reduce large scale destruction of the weaker states and near-permanent sufferings of its people.

\section{Theoretical Precepts: Constructivism and Ideas}

Unlike realism and liberalism, constructivism laid more emphasis on the people and ideas in their interactions of international relations. It was argued that, "state behavior is shaped by elite beliefs, identities, and social norms.... 
State and national interests are the result of the social identities of these actors." (Walt, 1998). Whereas, the constructivists tend to view the world through the prism of the power of ideas, culture, and exploration of more avenues of power that would make a state really superior to the other (Shoaib, 2013). Similarly, they do not view sovereignty in traditional context. These views helped this research to explore the possibilities of peace beyond the usual methods of war and diplomacy.

Constructivist theory rejects the basic assumption of neo-realist theory that the state of anarchy is a structural condition inherent in the system of states. Rather, it argues that "Anarchy is what states make of it." (Wendt, 1992). That is, anarchy is a condition of the system of states because states in some sense 'choose' to make it so. Anarchy is not an inherent fact of state-tostate relations. The constructivists are of the view that anarchic nature of the system of states can be changed.

Constructivists opine that states may have their identity and interest, but they must also share the ideas, beliefs, and the cultural beings of the people they are representing. Hence, they argued that constructivism remains more of a philosophically and theoretically informed perspective and approach to the empirical study of international relations (Ruggie, 1998).

Constructivism and its Desired Fundamentals at a Glance

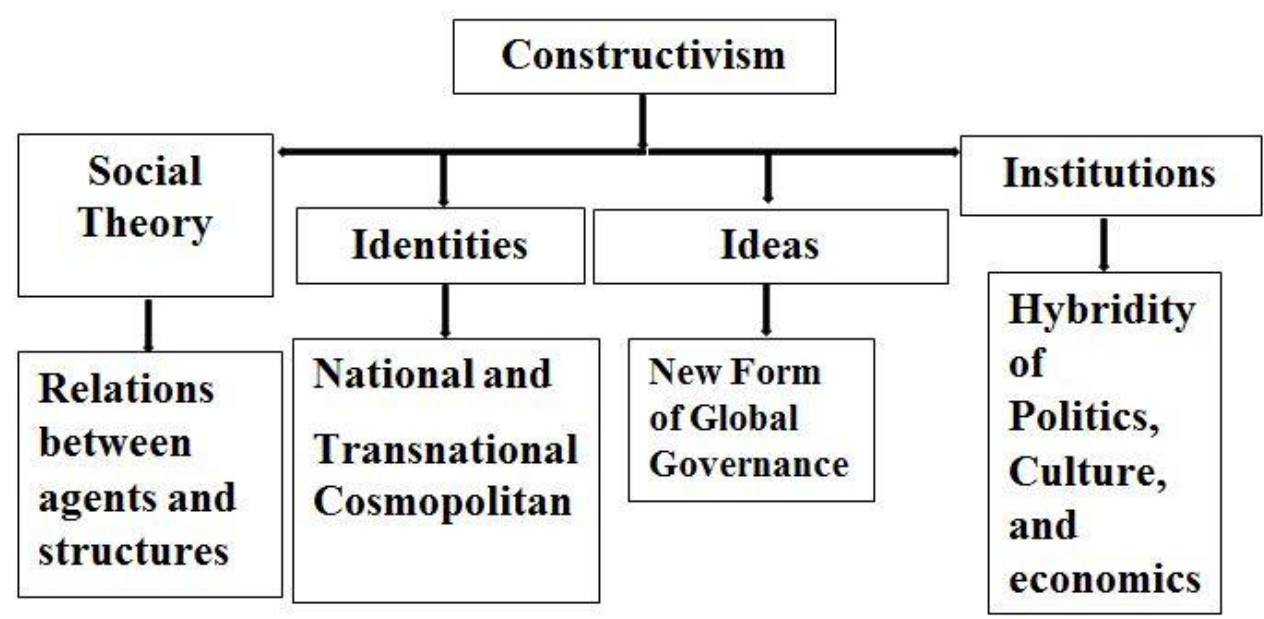

Figure-3

The Figure-3 reflects that Constructivists constantly proposed reviewing of old strategic thoughts and preferred newer grounds and ideas to resolve to evolving issue that may lead to conflicts. However, the practitioners only picked up certain ideas that suited them political gains and under the realist paradigm. For instance, human rights could be noble if applied across the globe uniformly, but it does not happen and hence, the proliferation of wars amongst the UMPs have continued at regular intervals. 


\section{A Revised Approach: 'Realizm'}

While developing the argument and characteristics of a realizer, this author took guidance from the 'Last Sermon' of Prophet Mohammad (Peace Be Upon Him), delivered to the Muslims attending the Hajj in year 632 C.E. For the time, it was a huge gathering, and the exact number of attendees could not be recorded. The following few lines from the Sermon were and particularly today are the most relevant for the purpose of this research. The Prophet Mohammad (Peace Be Upon Him) said:

All mankind is from Adam and Eve. An Arab has no superiority over a non-Arab, nor does a non-Arab have any superiority over an Arab; a white has no superiority over a black, nor does a black have any superiority over a white; [none have superiority over another] except by piety and good action.

The Sermon delivered at that time by Prophet Mohammad (Peace Be Upon Him), set the stage for the new Islamic Welfare State of Medinah. The entire text of the 'Last Sermon' would serve as great guidance for the humanity until it lasts, but the above lines should serve as an eye opener for us all in a general, and those responsible to manage the affairs of their states. This author reiterates that the gap between north and south, east and west, rich and poor, haves and have not's, has reached a level of extreme adversity. Therefore, the uncertainty for the sustainability or perhaps the survivability of the planet earth and the humanity has increased manifolds.

The term realizm denotes hybrid characteristics of a realist and an idealist or a liberalist. A realizer sees independence and sovereignty of the state as a Blessing, and therefore respects the same for other neighboring and regional countries. A realizer believes in the coordinated and even development of the region, so that the gap between rich and the poor is not too noticeable. A realizer would strive for equitable distribution of the resources in the region to ensure that his state does not become a migrant's destination.

A realizer proposes that conflicts and crises can be resolved through dialogue, provided the stakeholders are sincere and competent. A realizer would propose an incremental and reconciliatory approach to resolve conflicts with its neighbors and without using force against a potential adversary. However, if the use of force is essentially required to resolve a particular dispute, perhaps against a state which is being run as a protection racket, it must be proportionate and in shortest possible time, without causing much damage to the populace.

A realizer is one who prepares his state for the worst but strives to avoid getting in that situation. Power acquired by a realizer in the lead role, would serve as a deterrent against any authoritarian or totalitarian state in the region. His/her endeavor would be to avoid a military engagement with 'Equals' or 'Near-Equals.' However, against 'Unequal Military Power' it would aim to win an argument without fighting arms. A realizer would appreciate the 
ground reality and work closely to benefit the society. He or she would strive to improve regional security, thereby ensuring national security of the own state. A realizer would endeavor for the equitable development of each unit with an aim to minimize friction and work for the benefit of the region. A realizer believes in and strives to expand his area of influence in the region so that that the migration does not take place.

A realizer would encourage competition for the development and improvement of peoples' lives but would oppose killing people to remove even a tyrant regime. A realizer would advocate unity and afford opportunities to others also for the development of one's resources for the good of their people. A realizer would objectively decide between adequacy and sufficiency to accommodate more humans in the available means. A realizer would insist on regional development on the concept of 'Together we rise' to minimize inequality, which would lead to movement of people in search for better opportunities. The mass migrations bring with it host of other issues like unemployment, hunger, poverty, crime etc. A realizer would aim to enhance the capacity and opportunities of the relatively weaker state around it so that people do not move out of their own country of residence for want of safety, security, employment, food, and shelter and so forth.

On the front of international relations, a realizer would strive for 'Productive Engagement' with its neighbors and regional players. One could argue that there may be a huge gap of understanding between the governments and the people of any two states due to differing cultures and historical backgrounds. However, this author is of the view that if the political will exists, the policy of Productive Engagement would deliver. In fact, Policy of Productive Engagement calls for a sincere and dedicated effort to benefits from each other's experiences and expertise instead of mere photo sessions of the summit meetings.

This author argues, and suggests to study and analyze the speeches and actions of Pakistan's Prime Minister Imran Khan, whose efforts appear to be that of a realizer. Well before he became the Prime Minister of Pakistan, Khan was a proponent of dialogue with Afghan Taliban, insisting that military operations are not the solution to Afghan problems. He was against the drone strikes by the US against Taliban's alleged hideouts in Pakistan's Federally Administered Tribal Areas (FATA), bordering with Afghanistan. Unfortunately, he was labelled as 'Taliban Khan' at that time, but he was proved right when US President Donald Trump requested him in January 2019, to assist the US in talks with Taliban. Khan's efforts proved extremely beneficial in the recently concluded US-Taliban Peace Agreement in DohaQatar. The US-Taliban Peace Agreement signed on February 29, 2020 would help withdrawal of all foreign troops from Afghanistan in 14 months.

Since his assumption of office in August 2018, Khan has insisted on Indian Prime Minister Modi to join hands against hunger and poverty in South Asia. However, his offers were considered as a sign of weakness and India went ahead with its plan to annex Jammu and Kashmir (J\&K) through 
Constitutional Amendments in Article 370 and 35A, which guaranteed certain exclusive rights related to autonomy to the people of Kashmir. Moreover, India's hardline government also passed Citizen (Amendment) Act, 2019 on December 11, aimed at religious persecution of Muslim minority. Large scale demonstrations took place in many of the Indian states against religiously motivated laws, thus damaging India's age-old secular image. Following Pulwama attacks on an Indian military convoy by a Kashmiri freedom fighter on February 14, 2019, Indian Air Force (IAF) carried out an airstrike in Balakot, Pakistan on February 26, 2019. India claimed to have destroyed a terror training camp killing over 250 terrorists; a claim that Pakistan asked India to prove on location. Pakistan Air Force (PAF) responded the next day and shot down two IAF jets, the wreckage of at least one fell inside Pakistan controlled Kashmir and its pilot Wing Commander Abhinandan was taken in custody. However, Pakistan's PM showing gesture of goodwill handed over the captured pilot to India, expecting them to respond positively, but to no avail.

Likewise, PM Khan made a valiant effort to reduce tension between Saudi Arabia and Iran, and US and Iran, following the killing of Major General Soleimani, Commander of Iran's Islamic Revolutionary Guard Corps (IRGC), on January 3, 2020 in Iraq by the US. Khan is once again making effort to appeal to the US to lift sanctions on Iran, amid humanitarian crisis due widespread COVID-19. Also, he is making efforts to make the world realize that Afghan people are facing extreme hardship due to non-availability of the basic essentials and world must act to save Afghanistan from total collapse. For the purpose, Pakistan hosted an OIC Foreign Ministers 'Conference in Islamabad on 18 December 2021, after a gap of 41 years.

The very purpose of above examples about PM Khan is to suggest that realizers like him can prove to be game-changers, and may help in replacing wars with peaceful conclusions of the protracted conflicts around the world.

Proposed 'Realizm' and its Desired Fundamentals at a Glance

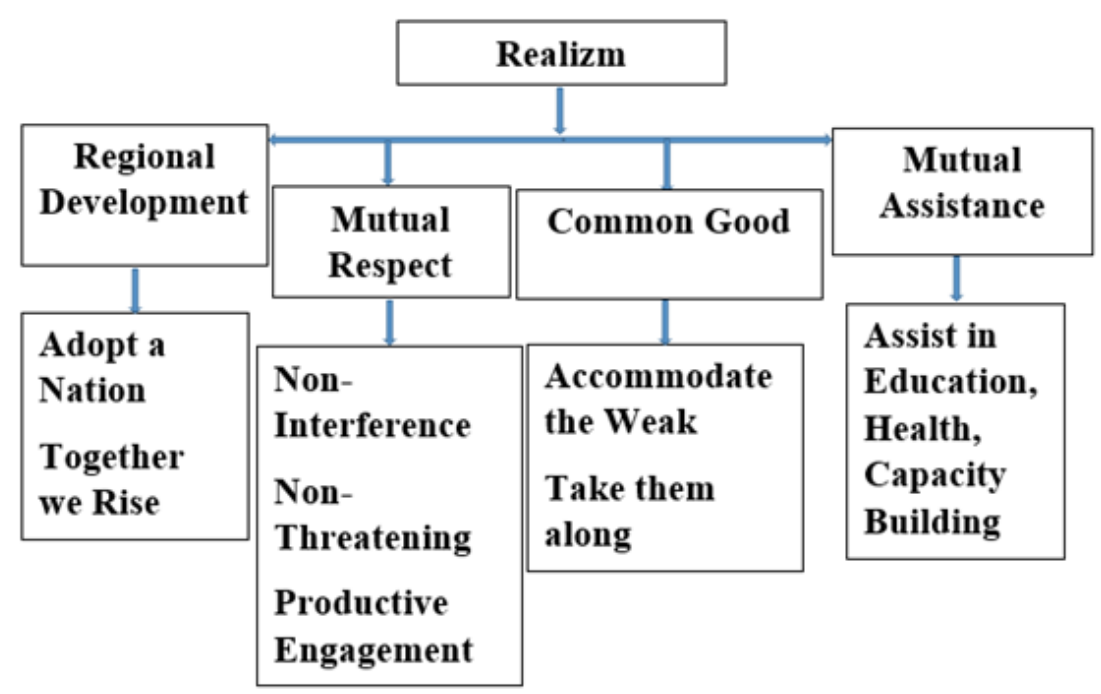




\section{Figure-4}

Figure-4.1 depicts desired fundamentals of realized paradigm briefly. It may not appear new, and it may appear idealistic. It may appear impossible, and it may appear not doable. However, a careful analysis of each term used above suggests that it is doable with little bit of determined effort. Adopting the nation might appear little demanding, but it is necessary to understand that it does not mean that the entire budget of the adopted state would become a liability on the donor state. It only means that an organized plan of 10-year term, is executed by a donor state to assist a poor recipient state in establishing educational institutions and health facilities. The primary responsibility would remain with the host country to make the best use of the available generosity.

Likewise, together we rise means carrying the poor states along to build their capacity to stand on their feet. Similarly, productive engagement would only be successful if the donors do not act as regional hegemons.

\section{Conclusion}

Theories related to social sciences remain under constant examination and review by scholars for their efficacies to deal international relations and events, and liberalism though considered the continuation of idealism, was considered an inadequate to deal with evolving world order. It is argued that neoliberals propounded that international institutions should promote global change, cooperation, peace, and prosperity through programs for reforms (Kegley \& Eugene, 2004). Whereas, "Security is essential, and institutions help to make security possible... These interactions will occur not just on security issues but on a whole suite of international issues including human rights (a classical liberal concern), the environment, immigration, and economics" (Keohane \& Nye, 2001). Therefore, an alternate approach is recommended and a new international relation theory realizm is presented to generate a discussion on its efficacy to marginalize the probabilities of wars and conflicts between unequal military powers to avoid the repeat of catastrophic results.

This author is cognizant of the fact that mere introduction of a new international relations' theory would not suffice in its purpose; but a beginning has to be made. The contours of the theory of realizm introduced in this paper, may appear too idealistic, or to some even unrealistic. But, the time has come to think differently. The world is experiencing something entirely different, and therefore the different things are required to be done by everybody in his or her capacity to recover out of it. The developed world should provide their surplus food items to the poor nations, and the developing world should send their medical staff to the west if they are lucky enough in this pandemic situation. The countries which are less affected should not consider themselves as safe for all times, and must reach out to those who are in difficult situation. 
By no means, this author is suggesting a world government, or a confederation of states, or the redrawing of the state boundaries, but the resetting of the existing systems, which is unjust for weak and poor. Going to wars should not be a cheap option or an easy decision that it is based on fakefolders to destroy a country and force its population to dark ages. Neither should war be so lucrative for the stronger nations that they do not explore other options at all. However, that would only be possible if people managing the affairs of the state are able to shed the perception of being selfish, and subservient to self-interest. It may sound too simple, and perhaps too sweet, and against human nature also; but it is certainly doable with out of the box thinking by a few responsible people who are willing to sacrifice only some of their comfort to make others feel a little better.

To conclude at the cost of repeating, this author is cognizant of the fact that present international system is anarchic and selfish. Moreover, this world is not an ideal place for each segment of the society. Natural and unnatural inequality between individual humans, groups, societies, states, and regions is present since the time immemorial. Moreover, the age-old system cannot be reset so easily even if the proposed realized paradigm is adopted. However, a beginning has to be made, and an effort must be initiated. Therefore, this revised theory of realizm needs to be debated vigorously to determine its efficacy or otherwise before it can find its rightful place in the literature.

\section{References}

Al Quran, Surah No. 5, Verse 45.

Jackson, R, \& Sorensen, G. (2007). Introduction to international relations: Theories and approaches. Third Edition. Oxford: Oxford University Press.

Kegley Jr, C. W., \& Wittkopf, E. R. (2004). World Politics Trends and Transformation (Belmont. USA: Thomson Wadsworth.

Kegley Jr, C. W., \& Wittkopf, E. R. (2004). World Politics Trends and Transformation (Belmont. USA: Thomson Wadsworth.

Keohane, R. O., \& Nye, J. S. (2001). Power and Interdependence. 3rd Edition. New York: Longman.

Laski, H. J. Harold J. (1935). The State in Theory and Practice. London: George Allen \& Unwin Ltd.

Morgenthau, H. (1948). Politics Among Nations. New York: Alfred. a. Knopf.

Morgenthau, H. J. (1973). Politics Among Nations: The Struggle For Power And Peace. $5^{\text {th }}$ Edition, New York: Alfred. a. Knopf.

Mingst, K. A. (2008). Essentials of International Relation. 4th Edition. New York: W.W. Norton \& Company. 
Ninkovic, P. (1957). Kant's Conviction of the Inevitability of Perpetual Peace, in Perpetual Peace, ed. Lewis White Beck. New York: Macmillan Co.

Nuechterlein, D. E. (1976).National Interests and Foreign Policy: A Conceptual Framework for Analysis and Decision-Making. Review of International Studies, 2(3), 246-266

Pervez, M. (2012). Security Community in South Asia: India-Pakistan. Routledge.

Ruggie, J. G. (1998). What makes the world hang together? Neo-utilitarianism and the social constructivist challenge. International organization, 52(4), 855-885.

Tilly, C. (1985). War-making and State-making as Organized Crime. In; Evans, PB, Rueschemeyer, D and Scocpol, T (eds) 1985 Bringing the State Back.

Walt, S. M. (2017). There's Still No Reason to Think the Kellogg-Briand Pact Accomplished Anything. Foreign Policy, 29.

Walt, S. M. (1998). International relations: one world, many theories. Foreign policy, 29-46.

Wendt, A. (1992). Anarchy is what states make of it: the social construction of power politics. International organization, 46(2), 391-425. 